\title{
Building Intercultural Bridges through TV Serials
}

\author{
Nektaria Palaiologou ${ }^{1}$, \\ School of Education, University of Western Macedonia \\ Vasilis Gialamas \\ National Capodistrian University of Athens
}

\begin{abstract}
A new trend in Greek TV is the screening of Turkish TV Serial, which seem to be very popular in many European countries. The effect of such Turkish Serial is so huge on the TV's audience that many times people prefer attending such soap-operas rather than other TV's very popular events, such as football games or Eurovision's competition. In this direction, as primary motivation for us, as academics and researchers was to explore the reasons for which the Greek audience likes attending Turkish TV Serial, focusing as an example on two very popular Turkish TV Serial which were shown at Greek TV, with sample University's students: these are "Binbir Gece" (Thousand and One Nights) and "Suleiman the Magnificent". The first TV Serial was shown by Greek TV in 2010 and the second since 2012. The protagonist in both TV Serial is the same actor, a very popular person for the Greek audience and both Serial were shown by Greece's big TV network, Ant1, at prime time, 9 p.m. Following, in this paper we present the methodology of the two surveys and their results, i.e. frequency tables, we implemented at the University of Western Macedonia, a regional University in Northern Greece; an analysis of the results and conclusions follow.
\end{abstract}

Key Words: Intercultural Education, research, TV Serial

\section{Introduction}

Turkish TV Serials, A New Trend or something more?

A new trend in Greek TV is the screening of Turkish TV Serial, which seem to be very popular in many European countries. The effect of such Turkish Serial is so huge on the TV's audience that many times people prefer attending such soap-operas rather than other TV's very popular events, such as football games or Eurovision's competition.

In this direction, as primary motivation for us, as academics and researchers was to explore the reasons for which the Greek audience likes attending Turkish TV Serial, focusing as an example on two very popular Turkish TV Serial which were shown at Greek TV, with sample University's students: these are "Binbir Gece" (Thousand and One Nights) and "Suleiman the Magnificent". The first TV Serial was shown by Greek TV in 2010 and the second since 2012. The protagonist in both TV Serial is the same actor, a very popular person for the Greek audience and both Serial were shown by Greece's big TV network, Ant1, at prime time, 9 p.m.

Concerning their plot, "Binbir Gece" focuses on a love story between a man coming from a wealthy family and a working girl, who feels desperate to raise her son who is ill. It is characteristic that this Serial has become so widespread in Greece that even in the first day of football's World Cup "Binbir Gece" captured 30.5 percent of viewers while the match between Uruguay and France caught just 28.2 percent. It was the first time that another programme beated the ratings of a soccer match in Greece.

"Suleiman the Magnificent" is a metaphor of the historical times in Turkey under the tenth and longest reigning Sultan of the Ottoman Empire from 1520 until 1566.

The high percentages of attendance of these Serial on the Greek TV audience made us thought that it would be interesting to explore the reasons for which these Serial seem to have great influence; so, this was the main research motivation for this study. (Also, in a few other European countries where these TV Serial are shown the percentage of attendance was high (eg. in Malta for Suleiman the Magnificent). The aim of this study was to show that TV could play a significant role in shaping up positive attitudes towards the "other", the "different" nations, and create bridges of intercultural communication.

\footnotetext{
${ }^{1}$ Correspondence author's email: nekpalaiologou@uowm.gr
} 
The main aim of this study is to explore the impact of Turkish TV Serials on the Greek audience and the explicit or implicit intentions of movie makers (i.e. sociological and political reasons). In accordance with the main aim are the following research questions:

-Do these specific TV Serials have a positive or negative impact on the Greek audience?

-Are there any explicit or implicit reasons (e.g. political, historical) for which these specific TV Serials are been shown?

-Do these specific TV Serials manage to create a climate that promotes intercultural understanding with our neighbours or not?

\section{Theoretical background: Cultural diversity flows and movies}

Cultural diversity is a multifaceted policy area with a number of different roots and with different emphasis and articulation at different territorial levels: intra-state, inter-state or transnational. In the latter context, the drive towards active policy on cultural diversity has a number of interconnected aspects. It could also accelerate phenomena such as homogenization, where common cultural patterns can be identified around the world (consumption of the same movies) or hybridization of culture (new forms of culture) (UNESCO 2009, p. 270). The diversity of cultural expressions can be studied by looking at the types of dichotomy in the supply and demand of cultural goods (e.g. movies) and services. Studying cultural flows between nations is a common tool for looking at diversity between nations. Imports and exports of films can be used to represent production and exchange diversity by indicating the origin of films entering a country, but measurement is severely limited by the technical constraints of customs and balance of payments data. Typically, films are exported to the destination market and then copied and distributed locally (UNESCO 2009, as above).

While an exported fi $\mathrm{lm}$ has an almost negligible value at customs, the bulk of international exchanges relating to its export are compiled in data from balance of payments, in the form of receipts for royalties and licenses through copies, exhibition rights and reproduction license fees.

Unfortunately, the 'cultural origin' of a cultural good is not easily identifiable. Only limited information is available on the origin of the cultural content of traded products. The rules applied to origin and destination of imported and exported products relate to the location of processing, but do not specify the origin of its cultural content..

A basic theoretical model of diversity was developed by Andrew Stirling (1998) and can be used to analyze diversity, while drawing on developments in other fields and tested in cultural domains such as publishing and music. The model is based on three components: variety, balance and disparity. Disparity is more difficult to measure and can often be subjective. Disparity of cultural expressions can be captured as a distance defined between types within a hierarchy (Koc-Damgaci, 2014).

To our point of view, these three components could be also used as a tool for the cultural analysis of movies, which have commonalities or differences at the situations and themes that they show.

Additionally, concerning the impact of TV on the audience there are classical studies on which we were based for the theoretical underpinnings of our work (Attallah 2011; Creeber, 2006; McKay, 2013; Willoughby, 2014).

At the next section is presented the methodology of the two surveys which were implemented at the University of Western Macedonia, a regional University in Northern Greece; an analysis of the results and conclusions follow.

\section{Method}

\section{Data Collection Tool}

For the needs of the surveys, a semi-structured questionnaire was developed, comprised of both close-ended and open-ended questions. The structure of the questionnaire is the following, in three parts: it starts with a few demographic questions which are addressed to the participants-sample. Specifically, gender, age, name of the department where students attend, year the surveys took place. Following, at the second part, the description of the main heroes, whom the participants are asked to describe, each hero with three adjectives, according to their main character as this is conceived by the participants. Finally, the third part of the questionnaire is a scale of attitudes, Likert type point 5, in order to measure participants' degree of agreement or dissonance to 15 certain statements (a-e) which refer to possible reasons (through questions 4-6) for which the Greek audience might like attending these two particular Turkish movies. The final question, number 7, is an open question where the participants, i.e. students express their own opinion about the impact of the Turkish movies on the Greek audience.

As has been already mentioned, the above questionnaire was developed for the needs and aims of the current study; thus, it is an original questionnaire that explores the attitudes of the 
participants/sample, providing also some personal data about the sample.

\section{Sample}

Both surveys took place at the University of Western Macedonia (UoWM) which until 2013 was comprised of 4 departments in the area of Florina in Western Macedonia, in Northern Greece, which is in the borderline with Skopje and Albania. The School of Education has two Departments of Education (Early Childhood and Primary), also the Department of Balkan Surveys and the Department of Arts. There is also the Technical University in Florina. The newly Polytechnic School, situated in Kozani, has been established. The area is characterized by its multiculturality, with migrants and natives who speak different dialects.

Concerning the sample of the study, in the first study, the sample was 81 students (N1) and in the second study it was 59 students (N2). In the first study, which took place in 2010-2011, the 74.1\% (60) of students was from the Technical Department, the $19.8 \%$ (16) from the Education Department and the 6.2\% (5) from the Balkan Surveys Department. The 4.9\% (4) were men and the 95.1\% (77) were women. The vast majority of the sample, 97.5\% (79) attended the specific TV serial very frequently. In the second study, which took place in $2013-2014$, the $49.2 \%$ (29) of students was from the Technical Department, the 28.8\% (17) from the Education Department and the 22\% (13) from the Balkan Surveys Department. The 16.9\% (10) were men and the $83.1 \%$ (49) were women. The vast majority of the sample, $76.3 \%$ (45) attended the specific TV serial very frequently.

All of the students were attending the last year of their undergraduate surveys.

There is only the sample of students that replies to the statements (Likert type scale), i.e. the issues which are explored. There is no comparison between students' replies in the two surveys.

\section{Data analysis}

As statistical method frequency analysis is used in these surveys. In the next section are presented the frequency tables, results of the first study and of the second study, using SPSS 20 version statistical software (IBM SPSS Statistics, 2011).

\section{Results}

In this paper, emphasis is given on the presentation of the results of a scale of attitudes, Likert type point 5 , in order to measure participants' degree of agreement or dissonance to 15 certain statements (a-e); these refer to possible reasons (questions 4-6) for which the Greek audience might like attending these two particular Turkish movies. The terms/concepts which are explored through these statements consist the operationalization of the terms. Following are the results for these six possible reasons, represented through frequency tables, for the two surveys consequently.

\section{Frequencies for the 1st study: Binbir Gece}

Question 4: Following are mentioned a few of the reasons for which the TV Serial 'Binbir Gece' might be popular. Please mention the degree of your agreement or dissonance in the four following, separate statements.

\section{First statement}

Table 1

The audience is identified with the heroes, the problems and difficulties they face in their everyday lives

\begin{tabular}{lcccc}
\hline & Frequency & Percent & Valid Percent & Cumulative Percent \\
\hline Totally Disagree & 5 & 6,2 & 6,2 & 6,2 \\
Partially Disagree & 16 & 19,8 & 19,8 & 25,9 \\
Not Sure & 32 & 39,5 & 39,5 & 65,4 \\
Partially Agree & 24 & 29,6 & 29,6 & 95,1 \\
Totally Agree & 4 & 4,9 & 4,9 & 100,0 \\
Total & 81 & 100,0 & 100,0 & \\
\hline
\end{tabular}

In Table 1, as we can see enough students, i.e. $29.6 \%$ (24) partially agree that one of the reasons for which "Binbir Gece" TV serial was popular is because the audience is identified with the heroes, the problems and difficulties they face in their everyday lives. However, 39.5\% (32) students are not so sure if the above could be considered one of the reasons for the popularity of this serial. 
Second statement

Table 2

The serial was popular because it showed values and customs which were common to the Greek people

\begin{tabular}{lcccc}
\hline & Frequency & Percent & Valid Percent & Cumulative Percent \\
\hline Totally Disagree & 2 & 2,5 & 2,5 & 2,5 \\
Partially Disagree & 7 & 8,6 & 8,6 & 11,1 \\
Not Sure & 35 & 43,2 & 43,2 & 54,3 \\
Partially Agree & 29 & 35,8 & 35,8 & 90,1 \\
Totally Agree & 8 & 9,9 & 9,9 & 100,0 \\
Total & 81 & 100,0 & 100,0 & \\
\hline
\end{tabular}

In Table 2, as we can see a lot of students, i.e. 35.8\% (29) partially agree that one of the reasons for which "Binbir Gece" TV serial was popular is because it showed values and customs which were common to the Greek people. However, 43.2\% (35) students are not so sure if the above could be considered one of the reasons for the popularity of this serial.

\section{Third statement}

Table 3

This serial is not a repetition of the classical American triptych (sex, money and violence).

\begin{tabular}{lcccc}
\hline & Frequency & Percent & Valid Percent & Cumulative Percent \\
\hline Partially Disagree & 7 & 8,6 & 8,6 & 8,6 \\
Not Sure & 19 & 23,5 & 23,5 & 32,1 \\
Partially Agree & 44 & 54,3 & 54,3 & 86,4 \\
Totally Agree & 11 & 13,6 & 13,6 & 100,0 \\
Total & 81 & 100,0 & 100,0 & \\
\hline
\end{tabular}

According to Table 3, the majority of students, i.e. 54.3\% (44) partially agree that one of the reasons for which "Binbir Gece" TV serial was popular is because it is not a repetition of the classical American soap operas, which usually show the triptych sex, money and violence.

\section{Fourth statement}

Table 4

This serial shows a way of everyday life in modern Turkey which is more familiar to Greek people

\begin{tabular}{lcccc}
\hline & Frequency & Percent & Valid Percent & Cumulative Percent \\
\hline Totally Disagree & 1 & 1,2 & 1,2 & 1,2 \\
Partially Disagree & 20 & 24,7 & 24,7 & 25,9 \\
Not Sure & 23 & 28,4 & 28,4 & 54,3 \\
Partially Agree & 31 & 38,3 & 38,3 & 92,6 \\
Totally Agree & 6 & 7,4 & 7,4 & 100,0 \\
Total & 81 & 100,0 & 100,0 & \\
\hline
\end{tabular}

According to Table 4, a lot of students, i.e. $38.3 \%$ (33) partially agree that one of the reasons for which "Binbir Gece" TV serial was popular is because it shows a way of everyday life in modern Turkey which is more familiar to Greek people, compared with the everyday life in other countries.

Question 5: Following are mentioned a few of the reasons for which the TV Serial 'Binbir Gece' might have a positive or negative effect on the Greek audience. Please mention the degree of your agreement or dissonance in the four following, separate statements

\footnotetext{
${ }^{2}$ In these two surveys the term "people" is used alternatively with the term "nation"
} 


\section{First statement}

Table 5

This serial softens the audience's fears towards the different in terms of religion

\begin{tabular}{lcccc}
\hline & Frequency & Percent & Valid Percent & Cumulative Percent \\
\hline Totally Disagree & 1 & 1,2 & 1,2 & 1,2 \\
Partially Disagree & 20 & 24,7 & 24,7 & 25,9 \\
Not Sure & 21 & 25,9 & 25,9 & 51,9 \\
Partially Agree & 24 & 29,6 & 29,6 & 81,5 \\
Totally Agree & 15 & 18,5 & 18,5 & 100,0 \\
Total & 81 & 100,0 & 100,0 & \\
\hline
\end{tabular}

According to Table 5, students' attitudes are divided. The issue of religion is a major issue which usually triggers fears to people in case of a different religion. The $29.6 \%$ (24) partially agree are not sure that one of the reasons for which "Binbir Gece" TV serial could have an effect (either positive or negative) on the Greek audience is because it dampens the audience's fears towards the different in terms of religion; in this case, towards the Muslims and Islam). On the other hand, the 24.7\% (20) students partially disagree, expressing the contrary attitude. Also, the $25.9 \%$ of students do not have a specific attitude about this issue.

\section{Second statement}

Table 6

This serial helps the Greek audience realize that the Greek nation has many commonalities with the Turkish neighbours in everyday life

\begin{tabular}{lllll}
\hline & Frequency & Percent & Valid Percent & Cumulative Percent \\
\hline Totally Disagree & 12 & 14,8 & 14,8 & 14,8 \\
Partially Disagree & 22 & 27,2 & 27,2 & 42,0 \\
Not Sure & 40 & 49,4 & 49,4 & 91,4 \\
Partially Agree & 7 & 8,6 & 8,6 & 100,0 \\
Total & 81 & 100,0 & 100,0 & \\
\hline
\end{tabular}

According to Table 6, a lot of students, i.e. 49.4\% (40) are not sure whether one of the reasons for which "Binbir Gece" TV serial could have an effect (either positive or negative) on the Greek audience might be because this serial helps the Greek audience realize that the Greek people has commonalities with the Turkish neighbours in everyday live, customs and some traditions.

\section{Third statement}

Table 7

This serial helps the audience to familiarize with the Muslims who live in Greece nowadays

\begin{tabular}{lcccc}
\hline & Frequency & Percent & Valid Percent & Cumulative Percent \\
\hline Totally Disagree & 2 & 2,5 & 2,5 & 2,5 \\
Partially Disagree & 5 & 6,2 & 6,2 & 8,6 \\
Not Sure & 14 & 17,3 & 17,3 & 25,9 \\
Partially Agree & 57 & 70,4 & 70,4 & 96,3 \\
Totally Agree & 3 & 3,7 & 3,7 & 100,0 \\
Total & 81 & 100,0 & 100,0 & \\
\hline
\end{tabular}

According to Table 7, a lot of students, i.e. $70.4 \%$ (57) partially agree that maybe this serial helps the Greek audience because it might help the audience get familiar with the Muslims who live in Greece. 
Table 8

This serial helps the audience to identify similarities with the Turkish people, in problems in everyday life.

\begin{tabular}{lcccc}
\hline & Frequency & Percent & Valid Percent & Cumulative Percent \\
\hline Totally Disagree & 20 & 24,7 & 24,7 & 24,7 \\
Partially Disagree & 28 & 34,6 & 34,6 & 59,3 \\
Not Sure & 25 & 30,9 & 30,9 & 90,1 \\
Partially Agree & 8 & 9,9 & 9,9 & 100,0 \\
Total & 81 & 100,0 & 100,0 & \\
\hline
\end{tabular}

According to Table 8 , a lot of students, i.e. $34.6 \%$ (28) partially disagree that maybe this serial helps the Greek audience to identify similarities with the Turkish people, in problems that we face in everyday life.

\section{Fifth statement}

Table 9

This serial aims to show a false picture of modern Turkey, by hiding a few dark sides

\begin{tabular}{lcccc}
\hline & Frequency & Percent & Valid Percent & Cumulative Percent \\
\hline Totally Disagree & 5 & 6,2 & 6,2 & 6,2 \\
Partially Disagree & 14 & 17,3 & 17,3 & 23,5 \\
Not Sure & 39 & 48,1 & 48,1 & 71,6 \\
Partially Agree & 22 & 27,2 & 27,2 & 98,8 \\
Totally Agree & 1 & 1,2 & 1,2 & 100,0 \\
Total & 81 & 100,0 & 100,0 & \\
\hline
\end{tabular}

According to Table 9, the $27.2 \%$ (22) partially agree that maybe this serial aims to show a false picture of modern Turkey, by hiding a few dark sides, like the tough rules of Saria (Shari'a), the difficult conditions of minorities, the working conditions of farmers. However, the majority of students, the $48.1 \%$ (39) neither agrees nor disagrees with this statement.

\section{Sixth statement}

Table 10

This serial aims to show that we have more commonalities with Turkish people rather than other Europeans

\begin{tabular}{lcccc}
\hline & Frequency & Percent & Valid Percent & Cumulative Percent \\
\hline Partially Disagree & 4 & 4,9 & 4,9 & 4,9 \\
Not Sure & 28 & 34,6 & 34,6 & 39,5 \\
Partially Agree & 21 & 25,9 & 25,9 & 65,4 \\
Totally Agree & 28 & 34,6 & 34,6 & 100,0 \\
Total & 81 & 100,0 & 100,0 & \\
\hline
\end{tabular}

According to Table 10, the $34.6 \%$ (28) totally agree that this serial aims to show that we have more commonalities with Turkish people rather than other Europeans. Also, a lot of students, the $25.9 \%$ (21) partially agree with this statement. 


\section{Seventh statement}

Table 11

This serial aims to show that we have more differences with Turkish people

\begin{tabular}{lrrrr}
\hline & Frequency & Percent & Valid Percent & Cumulative Percent \\
\hline Totally Disagree & 22 & 27,2 & 27,2 & 27,2 \\
Partially Disagree & 7 & 8,6 & 8,6 & 35,8 \\
Not Sure & 28 & 34,6 & 34,6 & 70,4 \\
Partially Agree & 22 & 27,2 & 27,2 & 97,5 \\
Totally Agree & 2 & 2,5 & 2,5 & 100,0 \\
Total & 81 & 100,0 & 100,0 & \\
\hline
\end{tabular}

According to Table 11, the $27.2 \%$ (22) partially agree that we have more differences with Turkish people rather than common characteristics and behaviours, while the majority of students, the $34.6 \%$ (28) neither agrees nor disagrees with this statement.

Question 6: Following are mentioned a few of the implicit political reasons and aims for which the TV Serial 'Binbir Gece' is shown, concerning modern Turkey's role. Please mention the degree of your agreement or dissonance in the four following, separate statements.

\section{First statement}

\section{Table 12}

The Greek nation is identified with the Turkish nation, and faces its possible fears for the political situation between the two countries

\begin{tabular}{lrrrr}
\hline & Frequency & Percent & Valid Percent & Cumulative Percent \\
\hline Totally Disagree & 4 & 4,9 & 4,9 & 4,9 \\
Partially Disagree & 24 & 29,6 & 29,6 & 34,6 \\
Not Sure & 27 & 33,3 & 33,3 & 67,9 \\
Partially Agree & 25 & 30,9 & 30,9 & 98,8 \\
Totally Agree & 1 & 1,2 & 1,2 & 100,0 \\
Total & 81 & 100,0 & 100,0 & \\
\hline
\end{tabular}

In Table 12, as we can see that a lot of students, i.e. $25 \%(30,9)$ either partially agree or disagree (29.6\%) that one of the implicit political reasons and aims for which the TV Serial 'Binbir Gece' is shown is that the Greek nation is identified with the Turkish nation, and faces its possible fears for the political situation between the two countries; while, 30.9\% (25) students are not so sure whether this is an existing implicit reason.

\section{Second statement}

Table 13

The Greek audience reliefs its possible mixed or confused feelings

\begin{tabular}{lrrrr}
\hline & Frequency & Percent & Valid Percent Cumulative Percent \\
\hline Totally Disagree & 19 & 23,5 & 23,5 & 23,5 \\
Partially Disagree & 19 & 23,6 & 23,5 & 46,9 \\
Not Sure & 25 & 30,9 & 30,9 & 77,8 \\
Partially Agree & 15 & 18,5 & 18,5 & 96,3 \\
Totally Agree & 3 & 3,7 & 3,7 & 100,0 \\
Total & 81 & 100,0 & 100,0 & \\
\hline
\end{tabular}

In Table 13, as we can see that enough students, i.e. $25 \%(30,9)$ are not sure whether one of the implicit political reasons and aims for which the TV Serial 'Binbir Gece' is shown is that the Greek audience reliefs possible mixed or confused feelings towards the Turkish people. It seems that the students are divided either in those who disagree partially or totally or in those who partially agree. 
Table 14

The serial passes the implicit message that modern Turkey is not a tough country

\begin{tabular}{lrrrr}
\hline & Frequency & Percent & Valid Percent & Cumulative Percent \\
\hline Totally Disagree & 14 & 17,3 & 17,3 & 17,3 \\
Partially Disagree & 8 & 9,9 & 9,9 & 27,2 \\
Not Sure & 25 & 30,9 & 30,9 & 58,0 \\
Partially Agree & 25 & 30,9 & 30,9 & 98,8 \\
Totally Agree & 9 & 11,1 & 11,1 & 100,0 \\
Total & 81 & 100,0 & 100,0 & \\
\hline
\end{tabular}

In Table 14, as we can see a lot of students, i.e. $25 \%(30,9)$ either partially agree or disagree $(29.6 \%)$ that one of the implicit political reasons and aims for which the TV Serial 'Binbir Gece' is shown is that the Greek nation is identified with the Turkish nation, and faces its possible fears for the political situation between the two countries; while, 30.9\% (25) students are not so sure whether this is an existing implicit reason.

Fourth statement

Table 15

The serial aims to create some kind of implicit propaganda for modern Turkey

\begin{tabular}{lrrrr}
\hline & Frequency & Percent & Valid Percent & Cumulative Percent \\
\hline Totally Disagree & 2 & 2,5 & 2,5 & 2,5 \\
Partially Disagree & 7 & 8,6 & 8,6 & 11,1 \\
Not Sure & 25 & 30,9 & 30,9 & 42,0 \\
Partially Agree & 35 & 43,2 & 43,2 & 85,2 \\
Totally Agree & 12 & 14,8 & 14,8 & 100,0 \\
Total & 81 & 100,0 & 100,0 & \\
\hline
\end{tabular}

In Table 15, a lot of students, i.e. 43,2\% (35) partially agree that one of the implicit political reasons and aims for which the TV Serial 'Binbir Gece' is shown is in order to pass implicit political messages for modern Turkey's role.

\section{Frequencies for the 2nd study: Suleiman the Magnificent}

Question 4: Following are mentioned a few of the reasons for which the TV Serial 'Suleiman the Magnificent' might be popular. Please mention the degree of your agreement or dissonance in the four following, separate statements.

\section{First statement}

Table 16

The audience is identified with the heroes, the problems and difficulties they face in their everyday lives.

\begin{tabular}{lcccc}
\hline & Frequency & Percent & Valid Percent & Cumulative Percent \\
\hline Totally Disagree & 4 & 6,8 & 6,8 & 6,8 \\
Partially Disagree & 10 & 16,9 & 16,9 & 23,7 \\
Not Sure & 31 & 52,5 & 52,5 & 76,3 \\
Partially Agree & 12 & 20,3 & 20,3 & 96,6 \\
Totally Agree & 2 & 3,4 & 3,4 & 100,0 \\
Total & 59 & 100,0 & 100,0 & \\
\hline
\end{tabular}

In Table 16, as we can see a lot of students, i.e. $20.3 \%$ (12) partially agree that one of the reasons for which "Suleiman the Magnificent" TV serial was popular is because the audience is identified with the heroes, the problems and difficulties they face in their everyday lives. However, $52.5 \%$ (31) students are not so sure if the above could be considered one of the reasons for the popularity of this serial. 


\section{Second statement}

Table 17

The serial showed main historic events from the Turkish history

\begin{tabular}{lcccc}
\hline & Frequency & Percent & Valid Percent & Cumulative Percent \\
\hline Totally Disagree & 2 & 3,4 & 3,4 & 3,4 \\
Partially Disagree & 6 & 10,2 & 10,2 & 13,6 \\
Not Sure & 34 & 57,6 & 57,6 & 71,2 \\
Partially Agree & 16 & 27,1 & 27,1 & 98,3 \\
Totally Agree & 1 & 1,7 & 1,7 & 100,0 \\
Total & 59 & 100,0 & 100,0 & \\
\hline
\end{tabular}

In Table 17, as we can see a lot of students, i.e. $27.1 \%$ (16) partially agree that one of the reasons for which "Suleiman the Magnificent" TV serial was popular is because it showed main historic events from the Turkish history. However, 57.6\% (34) students are not so sure if the above could be considered one of the reasons for the popularity of this serial.

\section{Third statement}

Table 18

This serial is not a repetition of the classical American triptych (sex, money and violence).

\begin{tabular}{lcccc}
\hline & Frequency & Percent & Valid Percent & Cumulative Percent \\
\hline Partially Disagree & 2 & 3,4 & 3,4 & 3,4 \\
Not Sure & 17 & 28,8 & 28,8 & 32,2 \\
Partially Agree & 34 & 57,6 & 57,6 & 89,8 \\
Totally Agree & 6 & 10,2 & 10,2 & 100,0 \\
Total & 59 & 100,0 & 100,0 & \\
\hline
\end{tabular}

According to Table 18, the majority of students, i.e. 57.6\% (34) partially agree that one of the reasons for which "Suleiman the Magnificent" TV serial was popular is because it is not a repetition of the classical American soap operas, which usually show the triptych sex, money and violence.

\section{Fourth statement}

Table 19

It is a historical serial which shows the life of an Emperor

\begin{tabular}{lcccc}
\hline & Frequency & Percent & Valid Percent & Cumulative Percent \\
\hline Totally Disagree & 1 & 1,7 & 1,7 & 1,7 \\
Partially Disagree & 20 & 33,9 & 33,9 & 35,6 \\
Not Sure & 17 & 28,8 & 28,8 & 64,4 \\
Partially Agree & 16 & 27,1 & 27,1 & 91,5 \\
Totally Agree & 5 & 8,5 & 8,5 & 100,0 \\
Total & 59 & 100,0 & 100,0 & \\
\hline
\end{tabular}

According to Table 19, a lot of students, i.e. $27.1 \%$ (16) partially agree that one of the reasons for which "Suleiman the Magnificent" TV serial was popular is because it shows the life of an Emperor, of a person who was a leader with an expansive policy directed to Europe of his times. On the other hand, the $33.9 \%$ (20) of the students believe the contrary.

Question 5: Following are mentioned a few of the reasons for which the TV Serial 'Suleiman the Magnificent' might have a positive or negative effect on the Greek audience. Please mention the degree of your agreement or dissonance in the seventh following, separate statements 


\section{First statement}

Table 20

This serial softens the audience's fears towards the different in terms of religion

\begin{tabular}{lrrrr}
\hline & Frequency & Percent & Valid Percent Cumulative Percent \\
\hline Totally Disagree & 11 & 18,6 & 18,6 & 18,6 \\
Partially Disagree & 13 & 22,0 & 22,0 & 40,7 \\
Not Sure & 29 & 49,2 & 49,2 & 89,8 \\
Partially Agree & 6 & 10,2 & 10,2 & 100,0 \\
Total & 59 & 100,0 & 100,0 & \\
\hline
\end{tabular}

According to Table 20, students' attitudes are divided. The issue of religion is a major issue which usually triggers fears to people in case of a different religion. The $22 \%$ (13) partially disagrees that one of the reasons for which "Suleiman the Magnificent" TV serial could have an effect (either positive or negative) on the Greek audience is because it dampens the audience's fears towards the different in terms of religion; in this case, towards the Muslims and Islam); while the 49.2\% (29) do not have a specific attitude about this issue.

\section{Second statement}

Table 21

This serial helps the Greek audience to find commonalities with the Turkish

\begin{tabular}{lcccc}
\hline & Frequency & Percent & Valid Percent & Cumulative Percent \\
\hline Totally Disagree & 2 & 3,4 & 3,4 & 3,4 \\
Partially Disagree & 4 & 6,8 & 6,8 & 10,2 \\
Not Sure & 12 & 20,3 & 20,3 & 30,5 \\
Partially Agree & 41 & 69,5 & 69,5 & 100,0 \\
Total & 59 & 100,0 & 100,0 & \\
\hline
\end{tabular}

According to Table 21, a lot of students, i.e. $69.5 \%$ (41) partially agree that maybe this serial helps the Greek audience to find commonalities with the Turkish neighbours.

\section{Third statement}

Table 22

This serial helps the Greek audience to get familiar to Muslim people

\begin{tabular}{lcccc}
\hline & Frequency & Percent & Valid Percent & Cumulative Percent \\
\hline Totally Disagree & 20 & 33,9 & 33,9 & 33,9 \\
Partially Disagree & 14 & 23,7 & 23,7 & 57,6 \\
Not Sure & 21 & 35,6 & 35,6 & 93,2 \\
Partially Agree & 4 & 6,8 & 6,8 & 100,0 \\
Total & 59 & 100,0 & 100,0 & \\
\hline
\end{tabular}

According to Table 22, the $33.9 \%$ (20) totally disagrees that maybe this serial helps the Greek audience to get familiar with the Muslims who live in Greece; while the $35.6 \%$ (21) is not sure about this.

\section{Fourth statement}

\section{Table 23}

This serial helps the Greek audience to identify similarities with the Turkish people, in everyday problems.

\begin{tabular}{lcccc}
\hline & Frequency & Percent & Valid Percent & Cumulative Percent \\
\hline Totally Disagree & 5 & 8,5 & 8,5 & 8,5 \\
Partially Disagree & 11 & 18,6 & 18,6 & 27,1 \\
Not Sure & 33 & 55,9 & 55,9 & 83,1 \\
Partially Agree & 10 & 16,9 & 16,9 & 100,0 \\
Total & 59 & 100,0 & 100,0 & \\
\hline
\end{tabular}


According to Table 23, a lot of students, i.e. $18.6 \%$ (11) partially disagree that maybe this serial helps the Greek audience to identify similarities with the Turkish people, in every day problems that it faces in life; while the 55.9\% (33) neither agrees nor disagrees with this statement.

\section{Fifth statement}

Table 24

This serial aims to show a false picture of modern Turkey, by hiding a few dark sides

\begin{tabular}{lcccc}
\hline & Frequency & Percent & Valid Percent & Cumulative Percent \\
\hline Partially Disagree & 1 & 1,7 & 1,7 & 1,7 \\
Not Sure & 24 & 40,7 & 40,7 & 42,4 \\
Partially Agree & 12 & 20,3 & 20,3 & 62,7 \\
Totally Agree & 22 & 37,3 & 37,3 & 100,0 \\
Total & 59 & 100,0 & 100,0 & \\
\hline
\end{tabular}

According to Table 24, the $37.3 \%$ (22) totally agree that maybe this serial aims to show a false picture of modern Turkey, by hiding a few dark sides, like the tough rules of Saria (Shari'a), the working conditions of farmers etc. However, the majority of students, the $40.7 \%$ (24) neither agrees nor disagrees with this statement.

\section{Sixth statement}

\section{Table 25}

This serial aims to show a few commonalities between the Greek and Turkish people

\begin{tabular}{lcccc}
\hline & Frequency & Percent & Valid Percent & Cumulative Percent \\
\hline Totally Disagree & 21 & 35,6 & 35,6 & 35,6 \\
Partially Disagree & 6 & 10,2 & 10,2 & 45,8 \\
Not Sure & 24 & 40,7 & 40,7 & 86,4 \\
Partially Agree & 7 & 11,9 & 11,9 & 98,3 \\
Totally Agree & 1 & 1,7 & 1,7 & 100,0 \\
Total & 59 & 100,0 & 100,0 & \\
\hline
\end{tabular}

According to Table 25 , the $35.6 \%$ (21) totally disagree that maybe this serial aims to show a few commonalities between the Greek and Turkish people. However, the majority of students, the $40.7 \%$ (24) cannot express a certain attitude about this statement.

\section{Seventh statement}

Table 26

This serial aims to show the differences between the Greek and Turkish people

\begin{tabular}{lcccc}
\hline & Frequency & Percent & Valid Percent & Cumulative Percent \\
\hline Totally Disagree & 1 & 1,7 & 1,7 & 1,7 \\
Partially Disagree & 13 & 22,0 & 22,0 & 23,7 \\
Not Sure & 25 & 42,4 & 42,4 & 66,1 \\
Partially Agree & 19 & 32,2 & 32,2 & 98,3 \\
Totally Agree & 1 & 1,7 & 1,7 & 100,0 \\
Total & 59 & 100,0 & 100,0 & \\
\hline
\end{tabular}

According to Table 26, the $32.2 \%$ (19) partially agrees that maybe this serial aims to show the differences between the Greek and Turkish people. However, the majority of students, the $42.4 \%(25)$ cannot express a certain attitude about this statement.

Question 6: Following are mentioned a few of the possible implicit reasons and aims of the TV Serial 'Suleiman the Magnificent' about modern Turkey's role. Please mention the degree of your agreement or dissonance in the five following, separate statements 
Table 27

The Greek nation is identified with the Turkish nation, and faces its possible fears for the contemporary political situation between the two countries

\begin{tabular}{lcccc}
\hline & Frequency & Percent & Valid Percent & Cumulative Percent \\
\hline Totally Disagree & 17 & 28,8 & 28,8 & 28,8 \\
Partially Disagree & 17 & 28,8 & 28,8 & 57,6 \\
Not Sure & 14 & 23,7 & 23,7 & 81,4 \\
Partially Agree & 8 & 13,6 & 13,6 & 94,9 \\
Totally Agree & 3 & 5,1 & 5,1 & 100,0 \\
Total & 59 & 100,0 & 100,0 & \\
\hline
\end{tabular}

According to Table 27 , the $28.8 \%$ (19) partially and the $28.8 \%$ (17) totally disagrees that maybe this serial aims to help the Greek nation to identify with the Turkish nation, and face its possible fears for the contemporary political situation between the two countries.

Second statement

Table 28

The Greek audience reliefs its possible mixed or confused feelings

\begin{tabular}{lcccc}
\hline & Frequency & Percent & Valid Percent & Cumulative Percent \\
\hline Totally Disagree & 9 & 15,3 & 15,3 & 15,3 \\
Partially Disagree & 3 & 5,1 & 5,1 & 20,3 \\
Not Sure & 25 & 42,4 & 42,4 & 62,7 \\
Partially Agree & 17 & 28,8 & 28,8 & 91,5 \\
Totally Agree & 5 & 8,5 & 8,5 & 100,0 \\
Total & 59 & 100,0 & 100,0 & \\
\hline
\end{tabular}

According to Table 28 , the $28.8 \%$ (17) partially agrees that maybe this serial aims to soften any mixed feelings of the Greeks towards the Turkish people; while the $42.4 \%$ is not sure about this.

\section{Third statement}

Table 29

This serial passes the implicit message that modern Turkey is not a tough country

\begin{tabular}{lcccc}
\hline & Frequency & Percent & Valid Percent & Cumulative Percent \\
\hline Totally Disagree & 2 & 3,4 & 3,4 & 3,4 \\
Partially Disagree & 7 & 11,9 & 11,9 & 15,3 \\
Not Sure & 22 & 37,3 & 37,3 & 52,5 \\
Partially Agree & 20 & 33,9 & 33,9 & 86,4 \\
Totally Agree & 8 & 13,6 & 13,6 & 100,0 \\
Total & 59 & 100,0 & 100,0 & \\
\hline
\end{tabular}

According to Table 29 , the $33.9 \%$ (20) partially agrees that maybe this serial aims to pass the implicit message that modern Turkey is not a tough country; while the $37.3 \%$ (22) is not sure about this.

\section{Fourth statement}

Table 30

This serial aims to create some kind of implicit propaganda for modern Turkey

\begin{tabular}{lcccc}
\hline & Frequency & Percent & Valid Percent & Cumulative Percent \\
\hline Totally Disagree & 12 & 20,3 & 20,3 & 20,3 \\
Partially Disagree & 6 & 10,2 & 10,2 & 30,5 \\
Not Sure & 13 & 22,0 & 22,0 & 52,5 \\
Partially Agree & 21 & 35,6 & 35,6 & 88,1 \\
Totally Agree & 7 & 11,9 & 11,9 & 100,0 \\
Total & 59 & 100,0 & 100,0 & \\
\hline
\end{tabular}


According to Table 30, the $35.6 \%$ (21) partially agrees that maybe this serial aims to create some kind of implicit propaganda for modern Turkey, by showing historical events of glory and imperialistic politics in the past.

\section{Limitations}

This is a small pilot study aiming to explore the explicit or implicit intentions of movie through the Turkish TV Serials, on the Greek audience. As a next step is the development of a semi-structured interview protocol, using qualitative methods of analysis. In this way, the answers could be analyzed in debth

\section{Discussion and Conclusion}

To our view, the results of the above two surveys seem to be very interesting mainly in two directions: a) in a sociological direction, with an intercultural perspective and b) in a political direction, with an international and global perspective.

To summarize the main findings, we can see that the Greek students from their answers seem to be agree that there are a few issues which refer to customs and everyday life commonalities which are the same between the two nations. Though they seem to be open and positive in such issues, which would promote interaction and getting to know each other better, however, it seems that they continue to have fears towards certain issues which are associated with the differences in Religion (e.g. Islam and Orthodox Church) and historical events of the past which placed the two people in a condition of rivalry and hatred (e.g. the Ottoman empire and enslavement of 400 years). These hidden fears make some students feel reluctant, afraid and skeptical towards the Turkish people even today. Also, these fears make a few students skeptical about the hidden aims of the Turkish serials which are shown today: i.e. that they aim to hide a few dark sides of the Turkish history or modern Turkey and show an ameliorated picture.

In this frame of interpretation of the above findings, it is interesting to mention that the "memory of the past" seems to be vivid in students' attitudes.

In conclusion, in a sociological dimension, the students of the sample could be divided in two groups: The first group seems to be more open to the "difference", expressing the attitude that there are more commonalities between the two people compared to the other Europeans. The second group seems to be still afraid, especially in issues of religious diversity and historical events.

Students' answers show a tendency either to be open, i.e. an intercultural approach, or hesitant, i.e. a nationalistic approach.

In a political direction, the students express their skepticism towards the hidden aims of the Turkish TV serials which movie makers would wish to pass in a laden way. Sociologists would assert that this in the frame of propaganda, the power of movies on the audience, trying to show an embellished picture of a situation and hide some dark aspects, i.e. at these two Turkish TV Serials, hard Sharia laws and discrimination which minorities face.

Whilst some others might believe the contrary: i.e. that old Turkey has a great past, with its good and bad aspects, and that modern Turkey has made significant progress to enter the EU. Of course, in this direction, these are political issues, whose interpretation and aims are beyond the scope of this paper.

In another one, but different sociological direction, "Binbir Gece" was also the talk of the town among Greeks who try to overcome the consequences of the financial crisis. "Vima's" leading commentator Kosmas Vidos had written in an article that "not only the model of soap opera between the two countries is similar but also that Binbir Gece is a good solution for TV networks hit by the crisis" (see: Hürriyet Daily News, 18th July 2010).

George Pleios, Professor of Media at the University of Athens, had a different explanation for this serial's success. He said that "Binbir Gece was not a sign that Greek society realized that the two cultures have a lot in common", but that "the success of this soap opera shows the growing fear and compassion that the Greek media as well as the society have for the Turkish government and Turkish society" (as above).

Prof. Pleios said: "For the Greek public and the media, Turkey is tough to deal with in foreign relations and is full of emotion. This emotional aspect is what differentiates Turkey from Europe. Greece has always wanted to be European, even though it has had more in common with non-European societies".

And he continued, concluding:

"As a result of Turkey's leading position in the region, this dichotomy is what leads to the Greek public watching Turkish soap operas to replace the loss of Greek identity in the international arena". 
Taking all the above and contradictory attitudes into consideration one thing is certain: Turkish TV Serials today have 'intruded' within the Greek homes, as a topic of discussion in our everyday lives, about our different neighbours.

Finally, it is up to us, to choose to be open to the different and create bridges of communication and human interaction, beyond any hidden political agendas, which we, as common people, we are not aware of.

On the other hand, some students have expressed the opinion that these two TV serials are shown by Greek TV, as the other Turkish TV serials, in a wave of new trend; like in case with the Brazilian TV serials some years ago, which had become a 'fashion' for some years.

Notwithstanding the different aforementioned reasons, one issue is certain: that the Turkish Serials are a new condition for the Greek TV, which seem to be very popular, at least for the time being. Also, not to forget that the influence and impact of TV on the audience could be either positive or negative, which means that "ex cathedra" TV and mass media, in general is a powerful tool that mold people's perceptions, ideas and attitudes. It is also evident that the multicultural climate of modern societies (Banks 2008) touches our everyday lives and point out the different traits we might have either as persons or as people living in different nations (Banks 2004).

At educational level, specifically at Universities an ultimate goal when teaching students about diversity issues is to help them acquire a broader perspective about embracing differences, getting rid of prejudices and develop an intercultural sensitivity (Yurtseven, Altun 2015) as well as develop themselves and function as global citizens (Palaiologou \& Dietz, 2015).

Acknowledgements: The authors would like to thank all the students who participated at these two surveys and for their interest in this study. Also, to express our thanks to the Editors of the Journal who had the courtesy to accept positively this international study, and for their critical comments.

\section{References}

Attallah, P. M. (2011). A Usable History For The Study Of Television. Canadian Review Of American Surveys/Revue Canadienne D'etudes Américaines, vol. 37, no 3, pp. 325-349. MLA International Bibliography (Web access 15 March 2014).

Banks, J. A. (2008). An introduction to multicultural education (4th ed.). USA: Pearson Education, INC.

Banks, J. A. (2004). Diversity and citizenship education: Global perspectives (1st ed.). USA: JosseyBass.

Creeber, G. (2006). The Joy Of Text?: Television And Textual Analysis. Critical Surveys In Television: Scholarly Surveys In Small Screen Fiction, vol. 1, no 1, pp. 81-88.MLA International Bibliography (Web access 10 March 2014).

Deardorff, D.K. (2011). Promoting understanding and development of intercultural dialogue and peace: A comparative analysis and global perspective of regional surveys on intercultural competence. Report of the State of the Arts and Perspectives on Intercultural Competences and Skills, UNESCO.

Hürriyet Daily News. (2010). Turkish soap opera becomes popular in Greece, article by Loutradis Christos, 18 July 2010.

Koç-Damgac1, F. (2014). Diversity Consciousness: Opening Our Minds to People, Cultures, and Opportunities, (D.R.Bucher, Book Review). Journal of Ethnic and Cultural Studies, 1(1), 4042.

McKay, L. (2013) Students to study TV as Literature. The Signpost (Web access 20 March 2014. http://www.wsusignpost.com/2012/03/23/students-will-study-television as-literature-19297).

Palaiologou, N. \& Dietz, G. (2014). Mapping the broad field of Multicultural and Intercultural Education, Cambridge Scholars Publishing.

UNESCO, (2009). Investing in Cultural Diversity and Intercultural Dialogue, UNESCO World Report,http://www.un.org/en/events/culturaldiversityday/pdf/Investing_in_cultural_diversity.p df (Web access on $1^{\text {st }}$ August 2015).

Yurtseven, N. \& Altun, S. (2015). Intercultural Sensitivity in Today's Global Classes: Teacher Candidates' Perception, Journal of Ethnic and Cultural Surveys, UKAM, vol. 2, no 1 http://journal.ukam.org/index.php?journal=JECS\&page=article\&op=view\&path[]=19 (Web access $7^{\text {th }}$ July 2015).

Willoughby, A. (2014). Television as Literature? Reading Castle as a Literary Text (Web access 18 March 2014.

https://www.academia.edu/1593655/Television_as_Literature_Reading_Castle_as_a_Literary 
Journal of Ethnic and Cultural Studies, 2015, Vol.2, No.2

-Text).

Appendix: The Questionnaire (in Greek language, combined for the two surveys) 


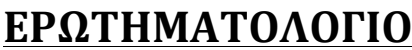

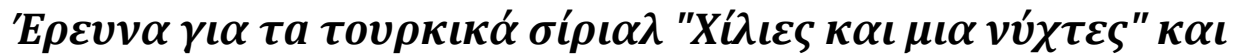

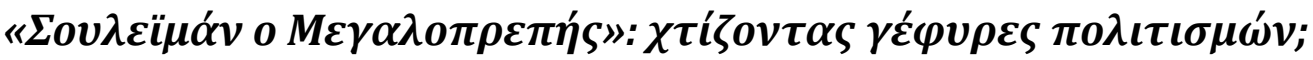

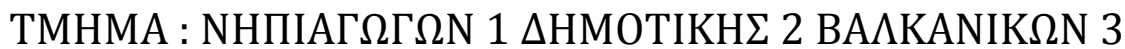

КАПОІО А $\Lambda \Lambda 0$

ETO $\Sigma \Sigma \Pi 0 \Upsilon \Delta \Omega \mathrm{N} \square \Phi \Upsilon \Lambda 0$

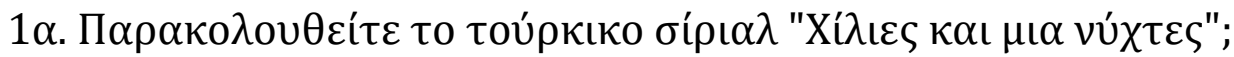

NAI 1

OXI 2

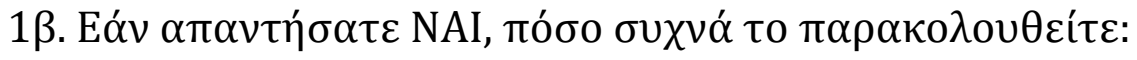

$\Delta$ EN XAN $\Omega$ EПEI $\Sigma O \Delta I O 1 \square$ IYXNA2 ГПАNIA3

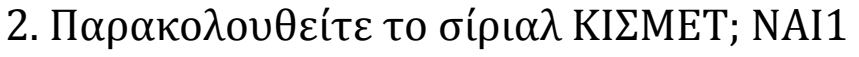

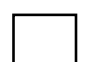

OXI2

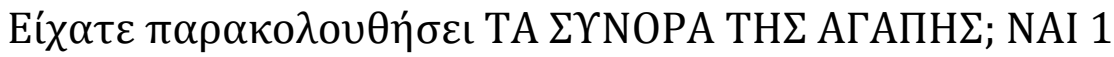

OXI 2

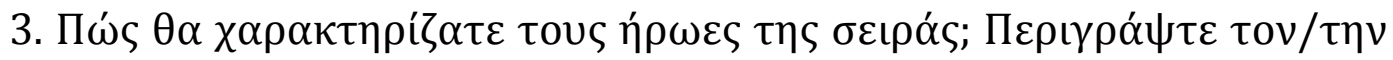

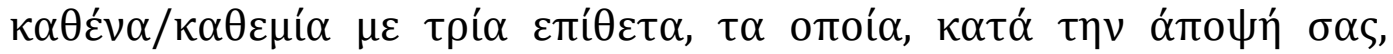

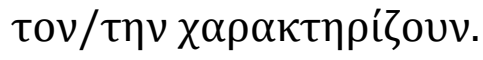

IEXPAZAT 1.

ONOYP

KEPEM

MIENOY 1.

NINET

MПOYPXAN 1.

A $\Lambda$ I KEMA 1.
2.

2.

2.

2.

2.

2.

2.
3.

3.

3.

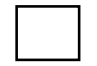


ФOYSOYN $1 . \quad 2 . \quad 3$.

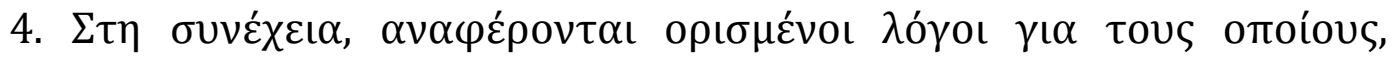

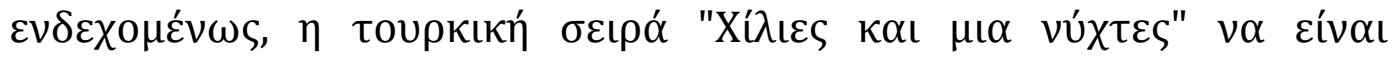

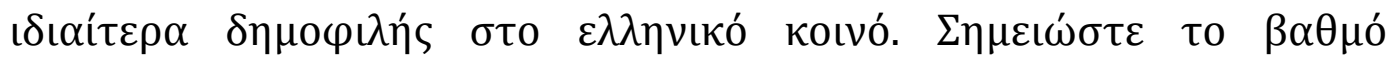

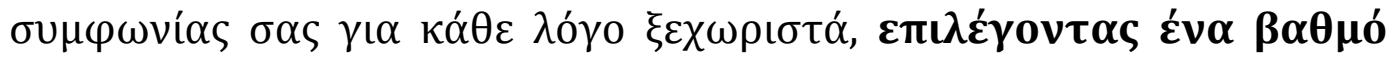

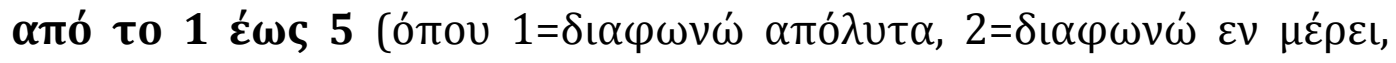

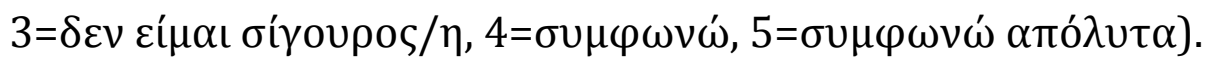

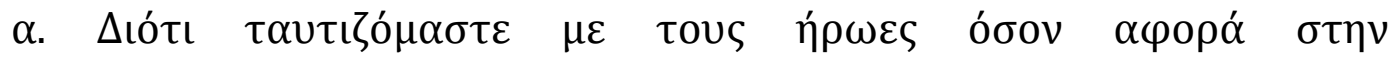

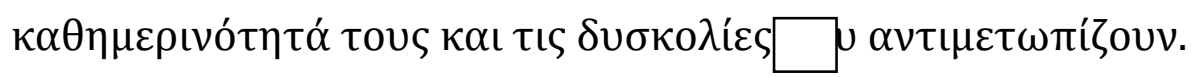

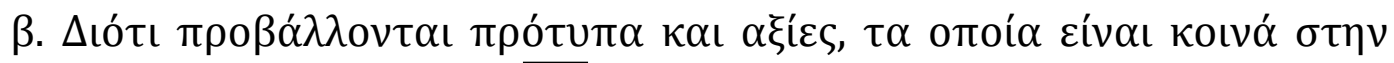

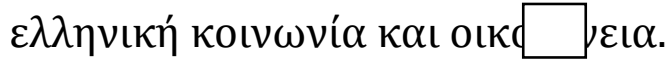

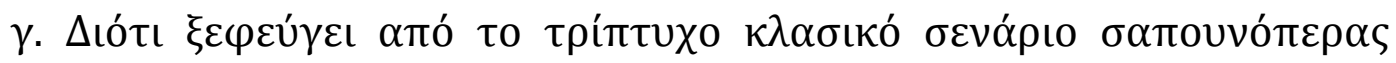

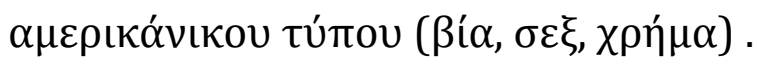

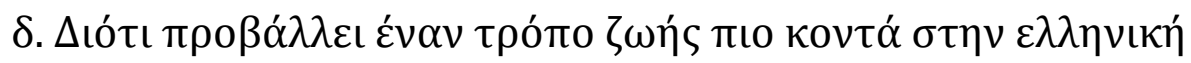
$\pi \rho \alpha \gamma \mu \alpha \tau \iota \kappa o ́ \tau \eta \tau \alpha$

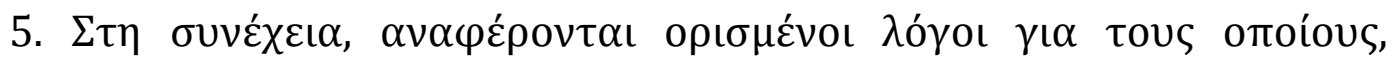

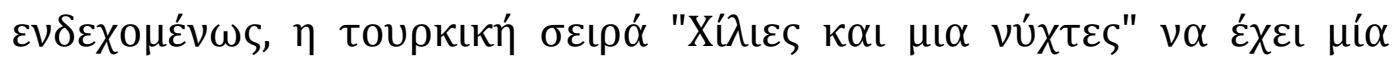

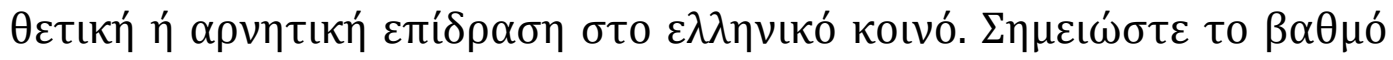

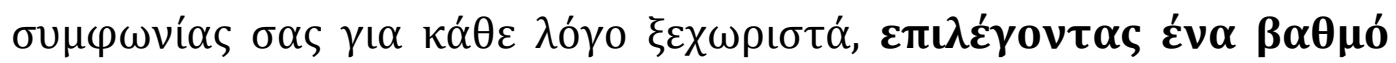

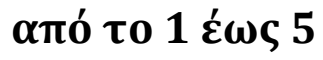

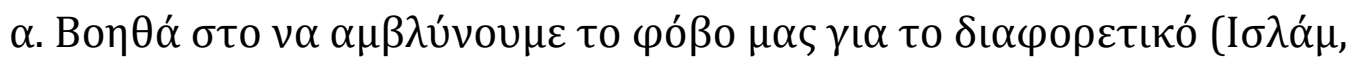

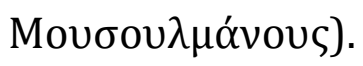

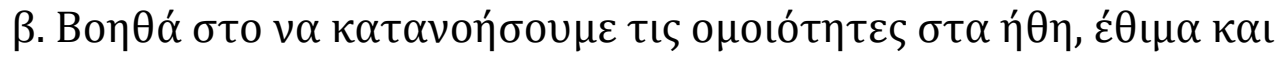

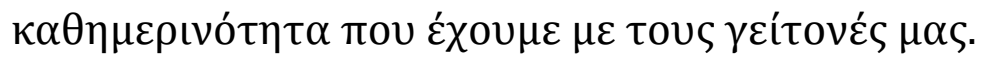

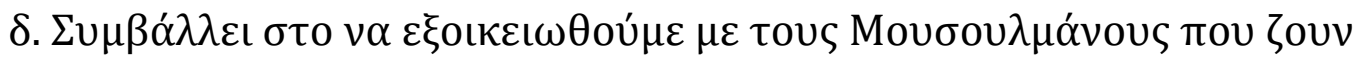
$\sigma \tau \eta \chi \omega ́ \rho \alpha \mu \alpha \square$

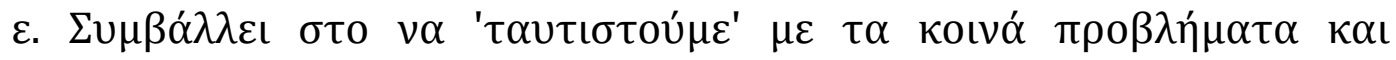

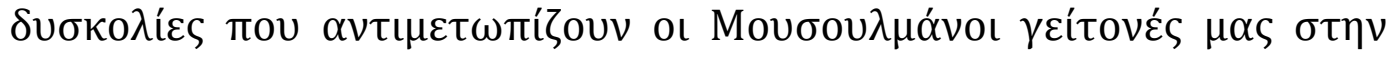

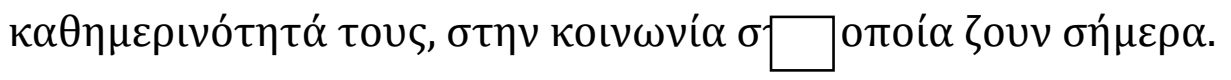

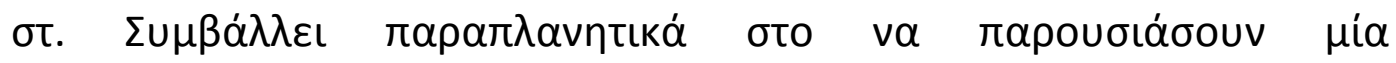




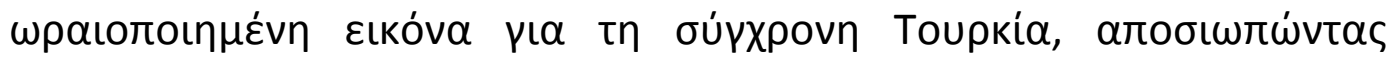

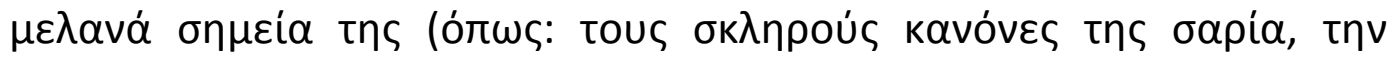

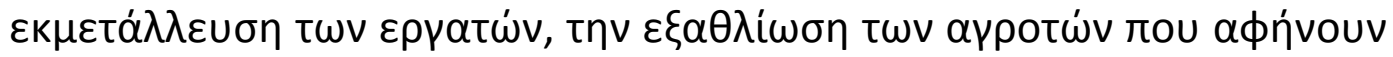

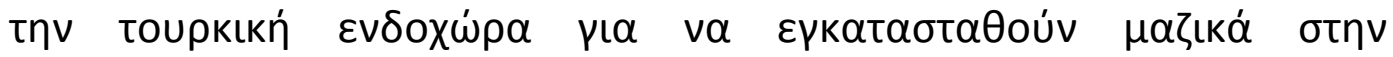

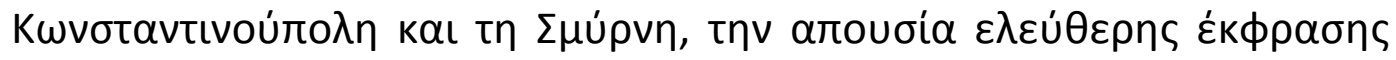

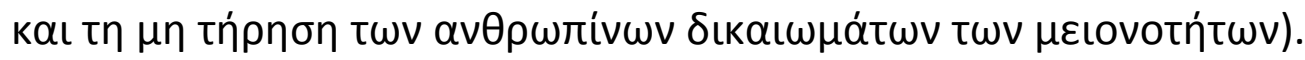




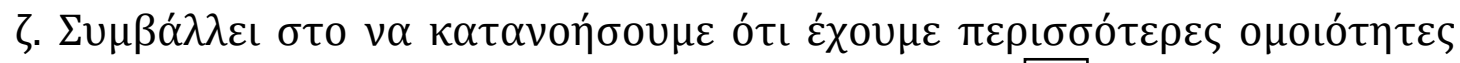

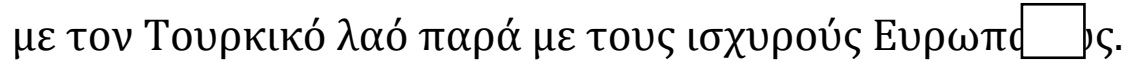

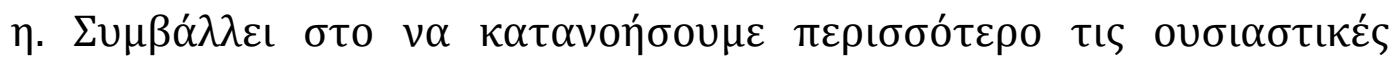

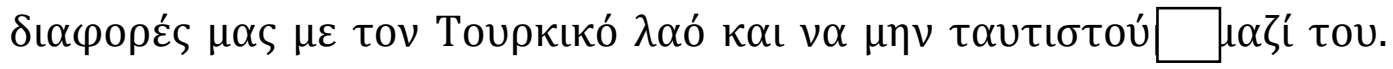

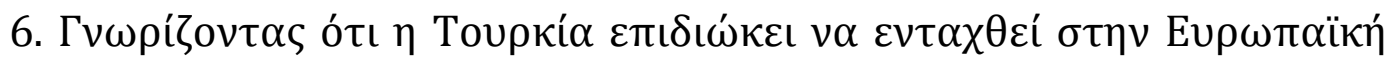

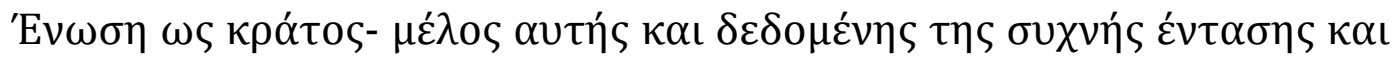

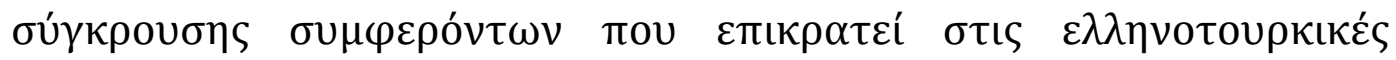

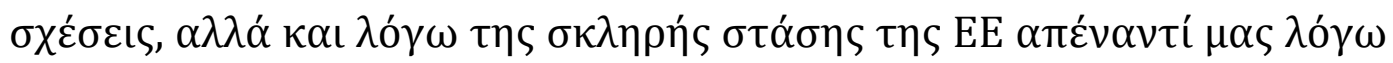

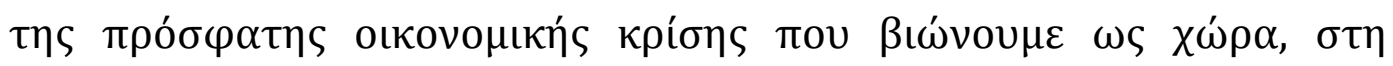

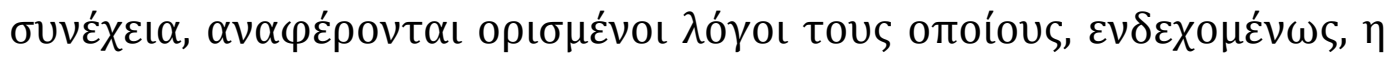

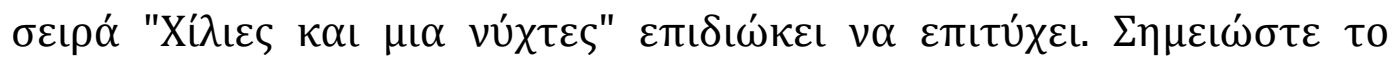

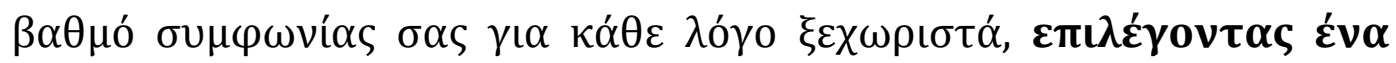

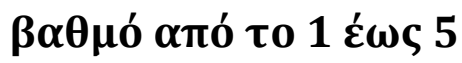

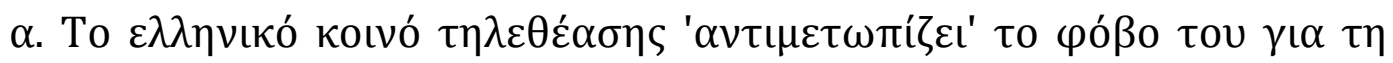

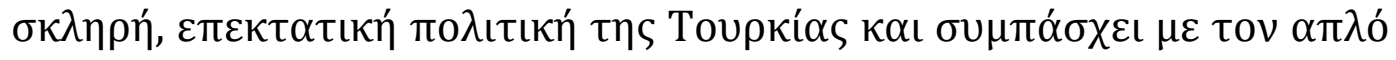

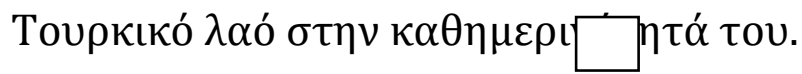

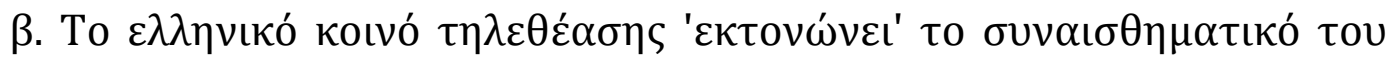

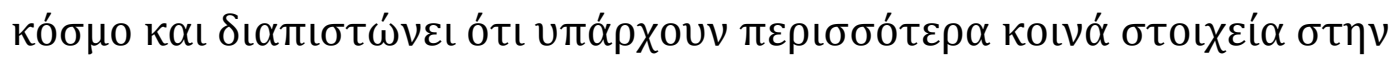

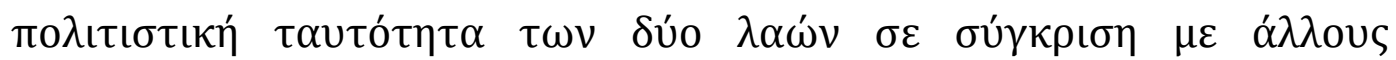

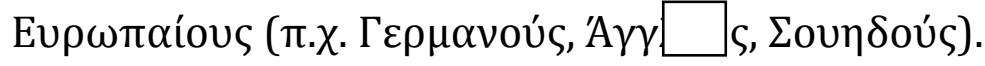

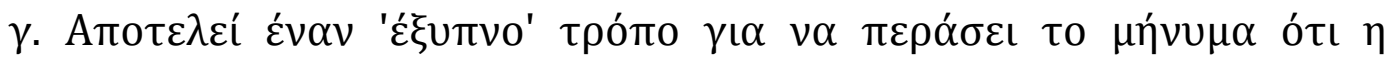

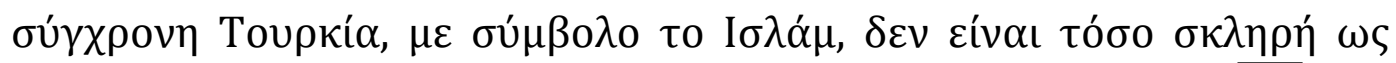

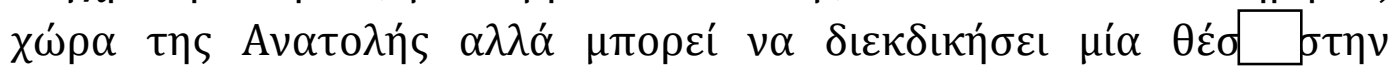

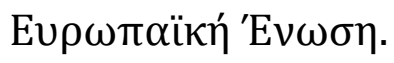

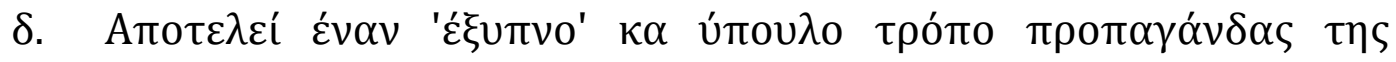

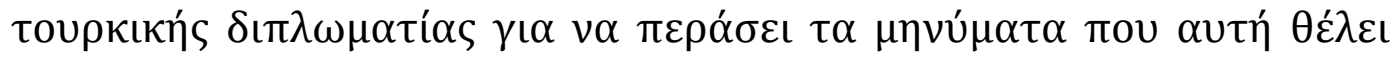

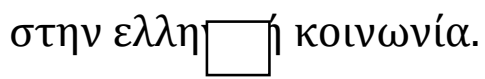

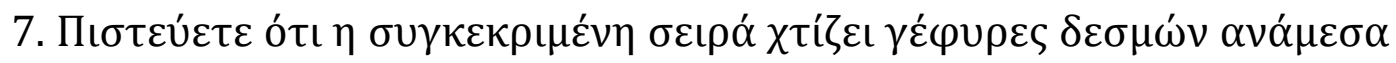

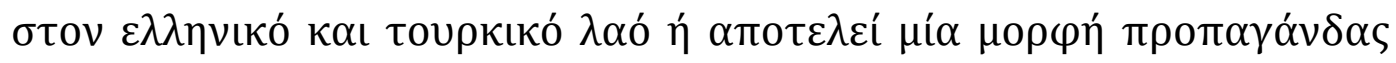

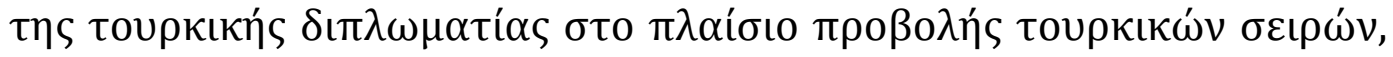




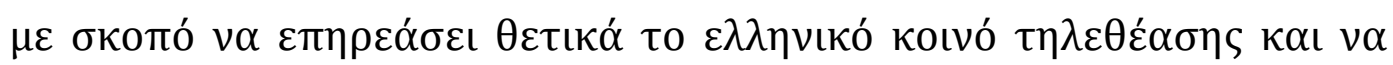

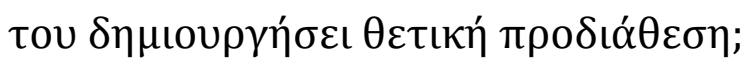

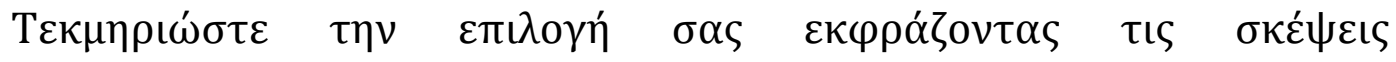
$\sigma \alpha \varsigma$ 